John Bengtson

(Association for the Study of Language in Prehistory; palaeojdb@hotmail.com)

\title{
Some notes on Euskaro-Caucasian phonology
}

\begin{abstract}
This paper explores a few features of the proposed reconstruction of Euskaro-Caucasian, the putative ancestor of Basque and the North Caucasian languages, as put forth in a recent monograph. Here some features of the consonantal system are discussed, namely (I) the development of proto-Euskaro-Caucasian ${ }^{*} m$ in Basque, (II) the non-initial Basque reflexes of Euskaro-Caucasian laryngeals, and (III) the Basque noun stem allomorphs involving an alternation between $/ \mathrm{rc}$ / and /śt/. It is shown how these details of Euskaro-Caucasian comparative phonology illuminate important unsolved problems of historical phonology on both the Basque and North Caucasian sides.
\end{abstract}

Keywords: Basque language, North Caucasian languages, comparative linguistics, EuskaroCaucasian language family, Proto-Euskaro-Caucasian, labial nasals, laryngeals, 'best explanation' hypothesis

In a recent monograph (Bengtson 2017: henceforth BCR) I have undertaken to outline a comprehensive scheme of comparative and historical phonology of the Euskaro-Caucasian languages, based on the comparison of my version of Proto-Basque, which relies heavily on Michelena's Fonética histórica vasca (1961, 1990, hereafter FHV), with Proto-North Caucasian and subsidiary proto-languages, according to the North Caucasian Etymological Dictionary by Nikolaev \& Starostin (1994, hereafter NCED). Since the complete discussion of historical phonology comprises hundreds of pages of the monograph, in this paper only selected aspects are discussed.

It will be reasoned here that an examination of this selection of phonological features helps to establish that the Euskaro-Caucasian hypothesis represents the best explanation for external relations of the Basque language, and concomitantly of the North Caucasian language family, and the fruitfulness of this hypothesis is demonstrated by the cross-validating nature of the three selected features (Proto-Basque ${ }^{*} m$; Proto-Basque ${ }^{*} h$ and ${ }^{*} h$ in non-initial positions; Basque noun stem allomorphs with the alternation $/ \mathrm{rc} / \sim /$ st $/$ ), in the sense that a particular etymology may exhibit the functions of two or even three of the selected features (see Conclusions). ${ }^{1}$

\section{The supposed non-existent phoneme * $m$ in Proto-Basque}

Michelena's FHV is an exceptionally important pioneering work that remains the most valuable reference for anyone attempting a study of Basque historical phonology. In the nineteenth chapter Michelena tackled the ancient consonantal system of Basque and proposed the opposition of fortis (tense or voiceless) vs. lenis (lax or voiced) consonants:

$\begin{array}{lllllllll}\text { FORTIS: } & - & \mathrm{t} & \mathrm{c} & \mathrm{c} & \mathrm{k} & \mathrm{N} & \mathrm{L} & \mathrm{R} \\ \text { LENIS: } & \mathrm{b} & \mathrm{d} & \mathrm{s} & \mathrm{s} & \mathrm{g} & \mathrm{n} & \mathrm{l} & \mathrm{r}\end{array}$

1 It is important to note that the putative "Euskaro-Caucasian" (EuC, or "Vasco-Caucasian") hypothesis is in no wise a contradiction of S. A. Starostin's "Sino-Caucasian” hypothesis; rather, EuC is considered to be a subgroup of Sino-Caucasian, as discussed by Bengtson \& G. Starostin (2015).

Journal of Language Relationship • Вопросы языкового родства • 16/4 (2018) • Pp. 247-264• ( ) The authors, 2018 
Notably absent from Michelena's scheme are the fortis labial $/ \mathrm{p} /$, the nasal labial $/ \mathrm{m} /$, and the fortis and lenis shushing sibilants $/ \check{c} /$ and $/ \check{s} /$, all present in modern and historically attested Basque.

Here we are only concerned with the purported absence of $/ \mathrm{m} /$ in Proto-Basque. Note that Michelena's proposal is hedged, as usual, with his characteristic caveat that such a hypothetical scheme should be treated with reservations, i.e., it was not a hard and fast doctrine. ${ }^{2} \mathrm{Nev}-$ ertheless, Trask (EDB 14) states as an absolute law "that no *m can be reconstructed for PreBasque. The modern $\mathbf{m}$ was introduced into the language by the phonological changes $\mathrm{P}^{* *}\{2\}$, $P^{* *}\{3\}$ and $P^{* *}\{7\}$, described in section 6."

The phonological rules Trask referred to are:

\section{P2. Assimilation of $/ \mathrm{n} /$}

P1 [Intervocalic /n/ loss] was competing with another change, which sometimes won out. Intervocalic $* / \mathrm{n} /$ was sporadically assimilated to a preceding high vowel: to $/ \tilde{\mathrm{n}} / \mathrm{after} / \mathrm{i} /$, to $/ \mathrm{m} / \mathrm{after} / \mathrm{u} /$. The first was very frequent, the second uncommon. For example, Latin pinum 'pine' was borrowed as *pinu, which developed to piñu, and Latin cunam 'cradle was borrowed as *kuna, which yields modern kuma in some varieties, alongside kua. ${ }^{3}$ This development, where it occurred, protected the nasal from loss by P1.

P3. /nb/ reduction

The cluster $* / \mathrm{nb} /$ is usually reduced to $/ \mathrm{m} /$. For example, *senbe yields common seme 'son', and *unbe yields common ume 'child'.

\section{P7. /b/ nasalization}

Original */b/ has almost invariably changed to $/ \mathrm{m} /$ in the configuration $* / \mathrm{bVn} /$, by a process of nasal assimilation. This process clearly preceded P1. For example, original *banats 'grapes' has developed to *manats and then to mahats; original *bini 'tongue' has developed *mini > mihi (and other variants); and Latin sabanum 'covering', borrowed as *sabanu, appears today as zamau in some varieties. In rare cases, mainly in loan words, ${ }^{*} / \mathrm{b} /$ developed to $/ \mathrm{m} /$ even in the absence of a conditioning nasal, as in *zubel 'holm oak' > B zumel. (Trask 2008: 25-26)

S. A. Starostin (1996: 122) objected to the notion of the complete absence of $/ \mathrm{m} /$ on the grounds of typology: "In Eurasia, at least, I do not know of any languages without a labial nasal ..."4 The prominent Vasconist Jacobsen (1995: 122) also demurred: “... I see no clear evidence that ${ }^{*} m$ - was absent from early Basque. ... I am not convinced that this assumption suffices to exclude from being native Basque several words in our sets [under discussion]: moko 'beak, front face' ..., ... muin 'pith, marrow, inner part' [also 'brain'] ..., and mutur 'snout, muzzle' ..."5

2 “En un trabajo aparte [Michelena 1957], basándonos principalmente en semejanzas en el comportamiento de los fonemas, sobre todo en la coincidencia de la neutralización de oposiciones en contextos análogos, llegamos, con todas las reservas que impone una restitución tan hipotética como ésta, a proponer la siguiente reconstrucción del sistema fonológico principal del vasco antiguo: ... [In a separate work (Michelena 1957), based mainly on similarities in the behavior of phonemes, especially in the coincidence of the neutralization of oppositions in analogous contexts, we arrive, with all the reservations that such a hypothetical restitution imposes, at proposing the following reconstruction of the main system of the phonology of ancient Basque: ...]" (Michelena 1990: 373-74: emphasis added by JDB).

3 More precisely: Latin cunam 'cradle' > (AN, Azk, Sal, R) kuna > (B, G, EB) kuma, alongside (AN, Sal) kua $\left(<{ }^{*} k \tilde{u} a\right)$ and other variants: (Z) khüña, (A) guia, (G) kuia, (AN) kuba, etc. (FHV 304; OEH).

4 In a response to this statement Trask (1996: 128) lists a number of languages, mostly in the Americas, that allegedly lack the phoneme /m/; outside of the Americas the only languages cited are the Burmic Hakka, Kpelle (Mande, West Africa), and the Papuan Rotokas. The absence of $/ \mathrm{m} /$ in Hakka and Kpelle is contrary to the information found in Ruhlen (1975: 203, 225); and WALS (Feature 18A: Absence of Common Consonants) cites only one language (Eyak, now extinct, in North America) with no bilabials or nasals, and none on other continents. Trask's claim that Navajo has no $/ \mathrm{m} /$ would be a surprise to the thousands of Navajos who use words such as 'amá 'mother, maternal aunt' and mã 'ii 'coyote' (though the existence of $/ \mathrm{m} /$ in Proto-Athabaskan is clearly questionable).

5 In BCR these words are connected with North Caucasian and other words; see the BCR sets Z.3, A.1, and A.18, respectively, and set I.19 in this paper. 
There is no dispute here with Trask's P2 rule, but some of the examples given for P3 and P7 are highly questionable. For example, *senbe and *unbe are based on the Aquitanian inscriptional forms SEMBE, OMBE- / VMME, which may or may not be identified with Basque seme 'son' and ume 'young, offspring, child' (better *hume, as in BN hume, Z hüme), which seems to be wobbly evidence for this grand generalization. There is no direct evidence for *banats 'grapes', ${ }^{6}$ where the ${ }^{*} b$ is simply generalized from other cases of ${ }^{*} b V n>{ }^{*} m V n$. Evidence is also dubious for the idea that zumel 'holm oak' comes from zur 'wood' + *bel- 'black' (EDB 134, 381), a somewhat folk-etymological guess unsupported by external evidence. ${ }^{7}$ As affirmed by Jacobsen (1995: 122) the whole problem with this claim of the non-existence of $/ \mathrm{m} /$ is overgeneralization; just because some instances of Basque /m/ can be ascribed to Trask's P2, P3, and P7 rules does not necessarily mean that all /m/s are of secondary origin. In Azkue's (1905) standard dictionary of Basque words with initial /m/ span pages 733 through 790;8 it is hard to believe that all of these $/ \mathrm{m} / \mathrm{s}$ are of secondary origin or borrowed. As will become clear in the etymologies cited below, there is no support in the Euskaro-Caucasian hypothesis for an absence of the phoneme $/ \mathrm{m} /$ in Proto-Basque, since a significant number of words in both Basque and North Caucasian which are considered putative cognates have ${ }^{*} m$ in both protolanguages.

Based on comparison of Basque with PNC there is substantial evidence that $\mathrm{PEuC}^{*} m$ is retained as Basque $/ \mathrm{m} /$, initially and medially, so the following etymologies require us to reexamine the proposal by Michelena (and enthusiastically seconded by Trask) that Pre-Basque had no phoneme ${ }^{*} m$.

On the other hand, we can find a certain grain of truth in Michelena's idea, in that no Basque dialects permit $/ \mathrm{m} /$ in final position, and all final nasals become $/ \mathrm{n} /$ or $/ \tilde{\mathrm{n}} /$ (see * gain, ${ }^{*}$ sain, and other examples, I.36-I.42). Furthermore PEuC clusters of the type *-mGw-, ${ }^{*}-m \chi w-$, ${ }^{*}-m x w$ - become Basque ${ }^{*} b$; and in most other medial PEuC clusters original ${ }^{*} m$ becomes $/ \mathrm{n} /$ or disappears in Basque. In the examples the letter-number combinations in bold, like C.28, P.20, refer to the etymological sets in BCR, which provide more detailed information: attested NC words and local Basque variants, and phonetic and semantic notes; only some of the representative forms are cited here.

Initial Basque *m-: < PEuC *m-, * $m \mathrm{H}-,{ }^{*} \mathrm{Hm}-,{ }^{*} n-\ldots-w-$ :

[I.1] Basque *maguli / malugi 'strawberry'; (AN) maguri, (Bzt, Sal) malubi id. PEC *niwg V 'a kind of berry'; Akhwakh muq'ali 'blackberry', Tabasaran niq:w / nimq: 'strawberry' (P.20)

[I.2] Basque *mahać 'grape(s)'; (BN, L) mahats, (B-Bergara, Leintza) magats id. (with metathesis) PNC *Eämćō 'apple; medlar'; Chechen ћamc 'medlar', Archi ạnš 'apple' (P.17) ${ }^{9}$

[I.3] Basque *mati-n, *mal- 'weak, soft, flexible'; (L) mali-n 'weak' PEC *mhălV-/ *mhănV'warm, weak'; Chechen mal-dan- 'to weaken, loosen' (R.63)

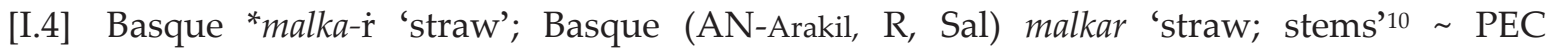
*mhĕlq wV 'root; shoot, offshoot'; Ingush mersa 'shoot, offspring; a single straw' (C.28)

6 BCR prefers the etymology positing Basque *mahać 'grapes': see etymology [I.2].

7 Cf. instead North Caucasian words such as Budukh žumol, Lezgi č:umal, Agul žimil 'cornel (tree)' (BCR C.2).

8 Likewise in Aulestia \& White's (1992) dictionary, where words with initial /m/ are found on pages 272-295.

9 Chechen hamc 'medlar', Khinalug mič 'apple', etc. For the semantic change of Basque 'grape' NC 'medlar, apple' cf. Rumanian poamă 'fruit, apple', Moldovan poamă 'grape', French pomme 'apple', pomme de terre 'potato', Venetian pomela 'laurel', etc. (REW 6645; Buck 5.71).

10 More precisely, 'straw (of vetch); stems of bean plants after threshing' (OEH). 
[I.5] Basque *manhai 'table'; (Z) mãhấñ id. PEC *mfăanne 'door; part of door'; Bezhta maha 'door-frame' (Q.9)'11

[I.6] Basque *mar[c]-harde 'fork, pruning hook'; (BN) martxite 'pruning hook'12 PNC * märć( $w) \bar{E}$ 'knife, sickle'; Hunzib mišu 'sickle'; Chamali mirča 'dagger' (Q.17)

[I.7] Basque *mardo 'robust; luxuriant', *mardu-l 'healthy, strong'; (G, B) mardul 'substantial, robust, sturdy' PEC *mōrtV 'male; man, hero'; Archi mett-le 'male', Chechen mayra 'husband; brave man' (R.58)

[I.8] Basque *maruhi/*mahuri 'strawberry', *mar-/*mar 'blackberry'; (BN-Aldude) mahurri 'strawberry', (Z) marhüga 'mulberry, blackberry' PEC *mer(2)V 'a kind of berry'; Lak mamari 'blackberry' (P.18; see I.56)

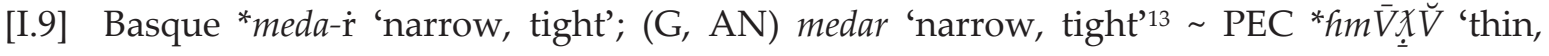
narrow'; Chechen nilxa 'thin, sparse', (with metathesis) Bezhta tłämmö 'thin, narrow', etc. (R.39)

[I.10] Basque *mihu-ri 'seed, kernel'; (BN) mihuri, (Z) mũhúi id. PEC *măhwV 'grain, seed; a kind of cereal'; Akhwakh mũhĩ 'seed, grain' (C.33)

[I.11] Basque * miko 'a little, little bit'; (BN, L) miko 'a little, a little bit, a pinch' PEC * mikwV 'small; young one'; Budukh mik'e 'few; a little, small' (R.32)

[I.12] Basque *minhi 'tongue', *minco 'speech', *mis-to 'sting (of bee), bite (of snake)'; (Z) mî́ñ, (B-arc) mĩi, mĩ 'tongue'; northern Basque mintzo 'speech, voice'14 PNC *mĕlç̣̆ "tongue'; Andi mic'i, Tabasaran melz, Dargi (dial.) limc:i id. (A.9)

[I.13] Basque *moc 'sex organs'; (c) motz 'cunnus, female genitals', motz-ak 'male genitals' PEC *măç̌u 'hair; fibre, strip'; Avar móč’o 'strip, piece' (A.61) $)^{15}$

[I.14] Basque *moku-ír 'tree trunk, tree base'; (R-Uztárroz) mokor 'stunted, rounded tree' PEC * mhŏqwe 'oak tree'; Tsakhur moq ‘ 'oak tree, acorn' (C.42)

[I.15] Basque *mardo 'bunch, group'; (B, G, AN) mordo 'bunch (of grapes); group, bunch, abundance'16 PEC *mărr[X]o 'handful, armful'; Hinukh mettu 'handful', Chechen mor 'armful' (L.9)

[I.16] Basque *moś-ko-ŕ 'tree trunk'; B, G, AN) moskor 'trunk (of a tree), burl'17 PNC *muçŭ / *çumŭ 'stick, wood'; Dargi murč' 'rod, stick' (C.41)

11 For NC 'door' Basque 'table', probably from 'board, plank', from which either tables or doors may be made; for typology cf. Indo-Aryan: Old Indic bhitta- '*split timber'; 'fragment; wall' > Dameli bit 'rafter, roof-plank, table'; Pashai (Areti) bidók 'table'; Panjabi bhitt 'half of double door, window', Panjabi (Kangra) bhittu 'board, door, half of double door', etc. (CDIAL 9493).

12 For the element *-harde cf. Bsq *śafiarde 'fork'. (G, AN, Z) matxite 'machete' is probably the source of Spanish machete, unlikely to be derived from Latin.

13 Northern Basque mehar is blended with Basque *menhe ‘thin' (BCR Z.12), of distinct origin.

14 A long discussion is devoted to "The case of Basque *minhi 'tongue' PNC *mĕlç̆ 'tongue" in BCR, pp. 219-24.

15 Compare the Basque and NC words with Burushaski *=múś-ki 'pubic hair' (SCG 143), an outgroup com-

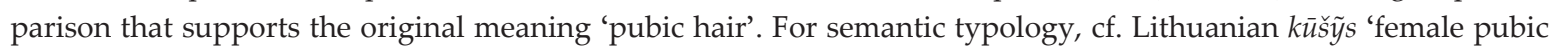
hair; vulva', kuškis 'wisp, tuft, bunch, shag (of hair)', Latvian kũsis 'pubic hair', kuškis 'wisp, tuft, bunch, shag (of hair)', (dial.) kūse 'vulva'; Persian kus 'pubic hair' (Steinbergs 1996, §3.2.2).

$16 \mathrm{BCR}$ has Basque *mordo, but mardo is attested in older Basque authors (e.g., Larramendi, 18 ${ }^{\text {th }} \mathrm{c}$.), and the metathesis morda in parts of Bizkaia; Proto-Basque *mardo (> (c) mordo by anticipatory assimilation) is a perfect phonetic match to PEC *măr[X]o. The original lateral (cf. PEC * ) leaves a trace in Basque (BN, L) molkho, (L) mulko 'cluster' (with diminutive suffix $-k o$ ).

17 Analyzed as *moś- (root) + *-ko- (diminutive suffix) $+{ }^{*}-\dot{r}$ (fossilized plural morpheme); see "General notes to etymologies," following Conclusions. 
[I.17] Basque *mośu 'nose, face, kiss'; (G) musu 'nose, snout, face, lip, kiss, point, tip' PEC *mhărçū 'protruding part'; Chechen-Ingush muc'ar 'snout, muzzle, trunk'; Avar móc':u 'teat, nipple; tip' (A.17)

[I.18] Basque *muga 'boundary, limit'; (c) muga [mura] id. PEC *mŏrqw chen това 'line, row' (L.2)

[I.19] Basque *mune 'brain, marrow, pith'; (Bzt) muiñ 'marrow, pith, brains' PEC *măfnnū 'brain, head'; Dargi mehe 'brain', Akhwakh mina 'head' (A.1)

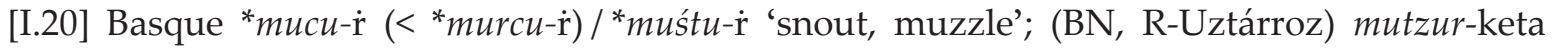
'rooting made by snout of a pig', (B) mustur 'snout, muzzle' PEC *mHărčwV 'snot, mucus, pus'; Andi maču 'snot', Chechen marš id. (A.19)

[I.21] Basque *muti-1 'boy; apprentice; worker'; (c) mutil id. PNC *mülx worker'; Dargi muru-1, (dial.) mur?u-1, murgu-1 'man, husband' (J.4) ${ }^{18}$

\section{Basque medial *-m-: $<$ PEuC *-m-, *-mH-:}

[I.22] Basque *ama 'mother', *eme / *ma- 'female' (with gender reversal) PEC * $2 \bar{m}$ V 'father; paternal uncle'; Avar emé-n 'father', Akwakh ima 'father', Tsakhur emi 'paternal uncle', etc. (J.10) ${ }^{19}$

[I.23] Basque *čamo 'weevil, caterpillar'; (B) txamo 'caterpillar', (G) txamo 'weevil', PEC *čı̆mhV/ *čww̌̆nhV 'flea; nit'; Hinukh č'ima 'nit', Tsakhur č'in 'flea' (B.45)

[I.24] Basque *čehume 'half-span'; (BN) xehume id. ${ }^{20}$ PNC *ç̌̆ $m \hbar V$ 'span'; Tsakhur č’ ịm / č’um, Agul čịb / čệb id. ${ }^{21}$ (L.7)

[I.25] Basque *čimiča 'bedbug', *čimi-ri- 'butterfly'; (B, G, Sal, R) tximitxa 'bedbug', (G) tximirrika, tximirrita 'butterfly' PEC *ḉimVĉ̣V 'fly, butterfly'; Tabasaran čamč' 'fly', Lak čimuča-li 'butterfly' (B.39)22

[I.26] Basque *e=meni 'to put'; (BN-arc) imeni, imini, (B, BN, Sal) imiñi id., alongside dissimilated forms (B, G, AN) ibini, ipini, ipiñi, etc. PEC*2ima- 'to stay, to be' <*2iman-; Archi imm(a)ex:as 'to stay', Khinalug $=m \ddot{a}$ 'to be' $(\mathbf{V} .27)^{23}$

[I.27] Basque *(eci-)[lamu] 'two days after tomorrow'; (B-arc) etzi-luma, (B) etzi-limo, etzi-lume, (A) \{esçirimu\} /ecirimu/ id. PEC ${ }^{*} € \breve{V} m V$ 'one day (two days) after tomorrow'; Batsbi lamŏ 'day after tomorrow', Karata la-di 'two days after tomorrow, three days hence' (H.9)

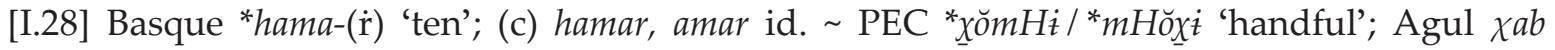
'armful', Udi max ${ }^{\S} a$ 'palm, handful' (M.7) ${ }^{24}$

[I.29] Basque *lami- / *limi ( *mili-) 'to lick, taste'; (AN, Sal, R) lami-ka-tu 'to lick' PEC *tamV 'licking, to lick'; Andi, Karata lam- 'to lick' (V.5)

18 Note the similar suffix $-l$ in Basque and Dargi.

19 In their global survey Bancel \& Matthey (2013; Bancel, et al. 2015: see Table 1) found that (P)APA words, which usually denote 'father' or 'dad', denote 'mother' (or 'mother's sister') in 6\% of languages surveyed, while (M)AMA words denote 'father' (or 'father's brother') in $26.1 \%$ of languages surveyed. In this case only two Dagestanian families (Avar-Andian and Lezgian) have words for 'father' ('paternal uncle' in Lezgian) derived from PEC * $2 \bar{e} m V$, while other North Caucasian words for 'father' derive from the expected (P)APA or (T)ATA types.

20 A measure $=$ distance between thumb and forefinger.

21 A measure $=$ distance between thumb and little finger

22 This seems to be an expressive variant of a similar root: Basque *simi $(n) \mathcal{c}(a) \sim$ PNC ${ }^{*}$ zimiz $\breve{A}$ (see I.32).

23 Older *2iman- is based on Hurrian mann-, Urartian man- 'to be'; Burushaski *man- 'to be, become'; ProtoYeniseian *pan- 'to sit' (SCG 140).

24 The difference of Basque /a/ NC/o/ could reflect ablaut allomorphs: see "General notes to etymologies," following Conclusions. 
[I.30] Basque *limu-ri 'slippery, moist, smooth'; limuri (Z) 'moist, humid', (G, AN) 'smooth, soft', (Z, Sal) 'slippery', etc. PEC * XH HwemV 'liquid' (adj.); Avar tt:amí-ya-, Andi t:emi, Lezgi žimi id. (R.53)

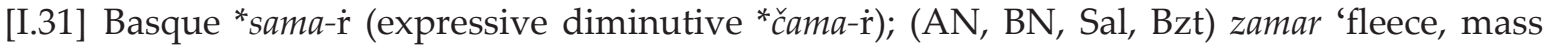
of wool shorn from a single sheep' PEC *çhwĕme 'eyebrow'; Kryz Sül-c'äm, Lak it:a-c'ani id. ${ }^{25}$ (A.23)

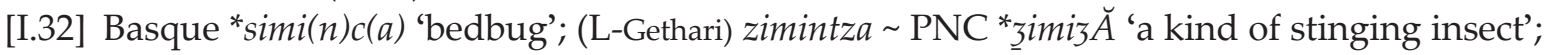
Dargi (Chiragh) zimiza-1 'ant', Tabasaran c'imc' 'ant' (B.38) ${ }^{26}$

[I.33] Basque *sumhe 'a kind of tree (willow, oak)'; (Z) zünhar 'a kind of elm tree', (Sal) zugar id. PEC *̌̌̆ŭmV 'bush, herb; a kind of fruit'; Chechen žKolam 'small bushes, shrubs'

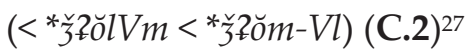

[I.34] Basque *śama 'neck'; (B) sama 'neck, throat' PEC *šs $V m V /$ * $m V \underline{s} V$ 'spine; edge'; Avar š:omé-li 'edge, end' (A.29)

[I.35] Basque *śami-n; (B, G, BN, L, Z) samin 'bitter, sour', also (BN, L, Z, Bzt) 'pungent, piquant, spicy' PEC *çĕmhV/ *çwĕnhV 'salt, salty'; Avar c':am 'salt' (R.15)

\section{Basque stem-final /n/ < PEuC *-m-, *-Hm-, ${ }^{*}-m H-:$}

[I.36] Basque *(beHa-)sun 'bile, gall'; (BN) behazun 'bile, gall; hatred, bitterness', (L-Sara)

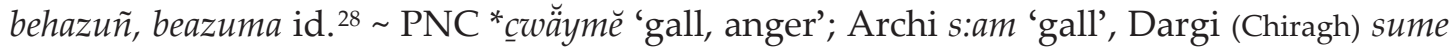
'gall, anger', (A.88)

[I.37] Basque *gain 'top, surface; above'; (Z) gañ PEC *hq̇wĕm $\bar{V}$ 'head, horn'; Tsakhur q'om 'summit, top', Andi G ${ }^{w}$ on 'horn' (I.13)

[I.38] Basque *hagin 'tooth' < PEuC +HaGimV; (BN, L) hagin 'molar tooth' (B) agin 'tooth, incisor tooth' (with transposition) PNC ${ }^{*} H \breve{e} m \underline{G} \breve{A}$ 'to bite'; Khinalug q'ini 'to eat', Karata $q^{\prime}: a m$ - id. (A.11) ${ }^{29}$

[I.39] Basque *kain; (B) kain 'fog, vapor, mist, storm clouds' PNC *kww̌̌mhV 'cloud, fog'; Khwarshi qema 'clouds' (G.6)

[I.40] Basque *sain 'vein, root, nerve, root (of hair)'; (Z) zañ 'nerve, vein, artery; root' PEC

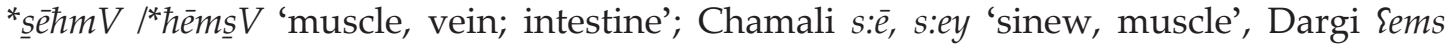
'muscle' (A.58)

[I.41] Basque *sen-[-bera] 'soft cheese, cream cheese'; (Z) zen-béa, (R) zén-bra id. PEC *Hžém̄̄ 'curds, butter'; Hinukh cen 'curds' Udi č: äin 'butter' (P.6)

[I.42] Basque *śoin 'shoulder, (upper) back'; (AN, BN, L) soin 'shoulder (general); midsection (of pork)', PEC *Hçwēymă / *Hçwēynă 'leg bone'; Tsakhur c'om 'shin-bone' (A.38)

25 The NC words are compounds with a word meaning 'eye', implying that PEC *çhwĕme itself originally had a more general meaning ('hair, fur'), like its Sino-Caucasian cognates: Burushaski *śe[m] 'wool'; ProtoYeniseian *caye 'hair'; Proto-Sino-Tibetan *chām: Lushai sam 'hair (of head)', Kinnauri tsam 'wool', Garo mik-sam 'eyebrow', Limbu mik-sā $\eta$ 'eyelashes' (SCG 27).

26 See I.25, which seems to be an expressive variant of this root.

27 Both Basque and EC have derivatives with the suffix *-atV: Basque: (B) zumel 'holm oak', (B, G) zumal-ika-r, zumal-aka-r 'a kind of willow or osier', (G) zumal-di 'grove’: EC: Budukh 亏̌umal 'cornel', Kryz žimel, Agul žimil id.; Hunzib šumal 'bushes, shrubs'; (with metathesis) Chechen žsolam 'small bushes'; Avar žulám / žulán 'cornel', etc. (NCED 1107).

28 The Bsq word is a compound of *beha- $+^{*}$-sun, the latter of which is compared with the EC words.

29 The transposition $+H a \underline{G} \underline{i m} V \sim{ }^{*} H \breve{e} m \underline{G} \breve{A}$ is typical of Sino-Caucasian and Euskaro-Caucasian (see BCR 9091). "There are many cases where we have to reconstruct verbal root structures like ${ }^{*} \mathrm{CVRV}$ or ${ }^{*} \mathrm{RVCV}$, based on [Sino-Tibetan] and Yenisseian evidence, while in NC their reflexes look like ${ }^{*}=\mathrm{VRCV}$ (with a reduction of the second vowel, and a regular development -CR- >-RC-)" (SCP, page 1). There seems to be a transposition similar to that of Basque *hagin in Andian languages: Andi q':am-, Chamali q':an- 'to bite', etc. (NCED 559). 
PEuC ${ }^{*}-m C$ - clusters: $\mathrm{PEuC}{ }^{*} m$ in these clusters is highly unstable in its Basque reflexes. In some cases $\mathrm{PEuC}{ }^{*}-m^{-}$, in clusters with sibilants, seems to disappear without a trace. Some convergent North Caucasian developments are cited as well:

[I.43] Basque ${ }^{*}=$ sari 'to put, sit' $\sim$ PEC * $=V m c \underline{c} V r$ 'to stand, stay'; Tsakhur uĺ-o=zar- 'to stand' (V.31)

[I.44] Basque *hace, *hac; (B, G, AN) atze 'back part (of house, boat, etc.)', (BN, L) hatz, atz 'track, trace, vestige, footprint' $30 \sim$ PNC * $h \bar{a} m c \underline{E} \breve{E}$ 'half, middle'; Tabasaran hac' 'half; body from head to waist', Ubykh 亏̌a 'back part' (I.8)

[I.45] Basque *hic 'word'; (BN, L, Z) hitz 'word' PNC *=[ī]mcŪ 'to speak, tell, talk'; Avar =ícine 'to say, tell' (L.10; V.52)

[I.46] Basque *isu 'fright, terror'; (B-Ispaster, Markina, G) izu, (AN, L, Z, R, Sal) izi id. PNC * $\hbar V m c \underline{V} V$ 'fear, fright'; Hunzib hĩč'- 'to fear, afraid' (K.6)

[I.47] Basque *listo- 'hornet, wasp', *e=lco 'gnat, midge, mosquito'31 PEC * XămçV 'a biting insect'; Akhwakh tac': u 'ant; bug, bedbug' (B.31)

[I.48] Basque *sisa-li, *sisa-ni; (Bzt) zizari 'worm', zizain 'leech' PEC *sēms̄ā 'tadpole, water flea, bug, ant'; Chechen sēsa 'tadpole', Tsakhur semsä-lä 'ant' (B.47)

In others PEuC *-m- is associated with the development of the Basque labial vowels /u/ or /o/: 32

[I.49] Basque *honda-r 'sand, residue, bottom'; (BN, L) hondar 'sand' PEC *2amtV 'earth, ground'; Khinalug ant id. (D.18) ${ }^{33}$

[I.50] Basque *hu[m]ki 'to touch'; (BN, L) hunki-tu, (B) uku-tu, iku-tu id. ${ }^{34} \sim$ PEC *fimkwV 'fist'; Bagwali hunk'a, Archi $\chi: i k$ id. (V.13)

[I.51] Basque *[H]uśu 'pus, serum'; (BN) usu PNC * $\{[a] m \underline{z} \bar{u}$ 'saliva, mucus; herpes'; Lak unts'u 'snot' (A.93)

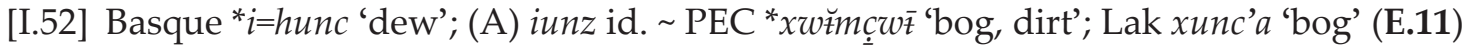

[1.53] Basque * $i=S O c$ 'frost, ice'; (c) izotz < PEuC +3Vmć(w)V ? PEC *3wVnć( $w) V$ 'snowdrift, snowstorm'; Lak zanč 'snow drift (in the mountains)' (G.16) ${ }^{35}$

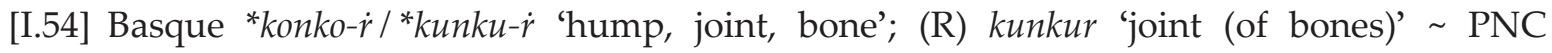
* $\dot{q} a ̆ m \dot{q}(w) \breve{a}$ 'knee, leg-bone'; Dargi q'u(n)q'a 'knee' (A.76)

[I.55] Basque *ondo1 'joint'; (c) gar-ondo 'nape, back of neck' PEC *zamdV 'joint, bone'; Avar hod 'spine, backbone' (A.77)

30 “Es razonablemente seguro que atze ['back part, past', etc.] no es sino hatz 'huella' ['track, trail', etc.] que, en su empleo local, adquirió no sólo un nuevo valor, sino además, una -e adventicia” (OEH).

31 EB liztor 'wasp', eltxo 'mosquito' (Aulestia \& White 1992); these seem to be permutations of the same root. Basque *listo- is an example of Basque "st-clusters" that correspond, under certain conditions, to PNC sibilants (usually tense) ${ }^{*} \underline{\underline{s}},{ }^{*} \underline{\underline{C}},{ }^{*} \underline{\underline{c}},{ }^{*} \underline{\underline{z}},{ }^{*} \underline{\underline{s}}$ (see BCR 138).

32 To judge from North Caucasian evidence, Basque *hog[w] $i$ and ${ }^{*}$ ortú-) originally had labial vowels: Basque *hogrw]i 'gums (mouth flesh)', (BN, L, Z) hobi PEC *hŏm Gwwŭ 'mouth, throat' (A.13); Basque *ortú-śi 'take off (shoes, stockings); *ortú-ć barefoot' PEC * ${ }^{*} m \underline{\underline{ } V}$ 'to put on (trousers, shoes)' (R.9; V.34); the Basque suffixes *-śi and *-ć apparently reverse ('take off footwear') the sense in EC ('put on footwear') (BCR 443).

33 Because this PEC reconstruction was based on only three Dagestanian languages, Tsezi, Hinukh, and Khinalug, the nature of the internal nasal (whether ${ }^{*} m$ or ${ }^{*} n$ ) was not clear. Based on the Basque evidence with the labial vowel /o/, * $m$ may be preferable for the PEuC stage.

34 In this word we have an unusual contrast between NE Basque /un/ /on/ (hunki-, onki-) vs. SW Basque /u/ $(u k i-)$, thus a tentative reconstruction *hu[m]ki-.

35 The lack of $/ \mathrm{n} /$ in the Basque word could suggest that it came from $P E u C+3 V m c ́(w) V$, related by labial metathesis to PEC * $3 w V n c ́(w) V$. An * $m$-cluster would more readily explain the loss of nasal and development of the labial vowel /o/ than an *n-cluster. 
[I.56] Basque *susa (in *mar-susa 'blackberry, mulberry'); (R) mar-zuza PEC * $3 i m z V$ 'a kind of berry (or flower, blossom)'; Agul ziwz-ar 'strawberry' (P.19; see I.8 for the morph *mar- / ${ }^{*}$ mar -$)$

From PEuC clusters of the type ${ }^{*}-m G w-,{ }^{*}-m \chi w-,{ }^{*}-m x w$ - nasality is lost and they become Basque $^{*}-b-$, in some cases only in certain dialects:

[I.57] Basque *fibai 'river'; (BN, L) hibai id. PEC *yimxw $\breve{A}$ 'river'; Godoberi inx:i 'river, brook' (E.7)

[I.58] Basque *hag[w]une / 'gahune 'foam'; (BN, L) hagun, (L) haboin, habuin, (Z) gahứn, etc. PEC *xwamV / *xwamxwV 'foam, liquid'; Dargi (Sirgokala) $x$ :umx:a 'foam' (E.10)

[I.59] Basque *hog[w] i 'gums (mouth flesh)' > (BN, L, Z) hobi; but (Bzt) ogi, (B, G) oi, (B) ui PEC * hŏmGwĭ 'mouth, throat'; Akhwakh oq':o 'throat' (A.13)

This appears to be a counter-example, not yet explained:

[I.60: see I.62] Basque *eiho 'to grind', *eihera 'mill' PNC *Hěm $\chi w V$ 'to grind', PEC *Hěm $\chi w V-r V$ 'mill, mill-stone' (Q.20; V.68)

In several cases the ${ }^{*}-m$ - (whether it disappears or remains as $/ n /$ ) is associated with the development of a Basque diphthong, /ai/, /ei/, /oi/, or /au/:

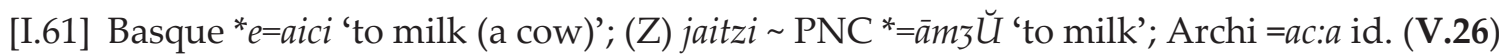

[I.62 = I.60] Basque *eiho 'to grind', *eihera 'mill'; (BN, L) eho 'to grind', (L) eihera 'mill'

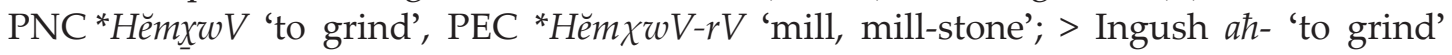
hayra 'mill', etc. (Q.20; V.68)

[I.63] Basque *e=roic 'cliff, fissure'; (c) erroitz PEC *hrŏmçwe 'stone'; Khinalug rïc'in 'stone' (D.13)

[I.64 = I.37] Basque *gain 'top, surface; above' PEC *hqंwĕm $\bar{V}$ 'head, horn' (I.13)

[I.65] Basque *gau / *gab- 'night'; (c) gau, (AN-Ulzama) gabe id. Proto-Lezgian * $\chi^{\varsigma}$ :am: / * $\chi^{\varsigma}$ :an:

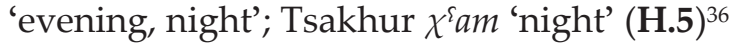

[I.66] Basque *haic 'stone, rock, crag'; (BN) haitz 'rock, stone' PNC *hāmVc̣̆o 'stone'; Avar Suc': id. (D.15)

[I.67] Basque *Hainc-eihar 'frost'; 37 (B-Oñate) aintzigar 'faint frost on leaves', (G-Tolosa) antzigar 'fine-grained snow' PNC * yămz $\breve{A}$ 'snow'; Tindi anzi 'snow' (G.15)

[I.68] Basque *haise 'wind'; (L) haize 'wind, air' PNC *2ăms a 'breath, soul; cloud, sky; god'; Akhwakh as:i 'breath', Udi haso 'cloud' (G.3)

[I.69] Basque *hauć 'ashes, powder'; (L) hauts id. PEC *yōmćV 'earth'; Batsbi yobst' id. (F.5)

[I.70] Basque *hauśin/ *haśuin 'nettle'; (BN, L) hausin id. PEC *hwāmšzi 'a kind of herb or weed'; Agul $\hbar a \check{s}^{w}$ 'caraway' (C.23)

[I.71 = I.39] Basque *kain 'fog, clouds' PNC *kw w̌mhV 'cloud, fog' (G.6)

36 S. A. Starostin cited these forms as Proto-Lezgian * $\chi$ I:am: / $\chi I$ :an: 'evening, night', with a pharyngealized voiceless uvular fricative, the symbol /I/ (палочка) signifying pharyngealization, and reconstructed Proto-SinoCaucasian * $\chi V ́[n] H V$ 'dark', based on Basque *gau 'night', Proto-Lezgian * $\chi I$ :an: 'evening', PY * $\chi 02 n$ - 'dark', and PST * $\gamma V m(H)$ 'dark, shade' (SCG 245-6; also TOB: Sino-Caucasian Database). With the symbol *[n:] in the reconstruction Starostin left open the possibility of a different nasal, namely * $m$;, which is supported by the PST form, the Proto-Lezgian alternate form * $\chi$ I:am: 'evening' (Tsakhur $\chi^{\wedge} a m$ 'night'), and the Basque labials in * $g a u$ 'night', *gab- (in compounds).

37 The Basque word seems to be a compound of *Hainc- + *eihar 'dry' (BCR R.22), i.e. 'dry snow'. 
[I.72] Basque *koipe 'rendered fat, grease'; (AN, BN, L) goipe 'butter, animal fat, melted fat, grease' PEC *kāmpā 'butter; sour cream'; Tindi k’wabi ‘sour cream' (P.9)

[I.73] Basque *lainho 'fog, mist, vapor'; (BN, L) lanho 'vapor', (Z) lãnhú 'mist, fog' < PEuC +X.amHV (with metathesis) PEC * hemX̆Ă 'dream'; Godoberi hanlu 'fog, cloud', Karata hantt'u id. (G.7)

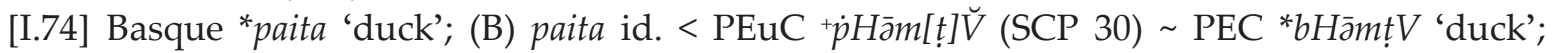
Dargi bat' id. (N.24)

[1.75] Basque *śaie 'vulture', (arc) 'eagle'; (B, G, BN, Z) sai 'vulture' PEC *çwäm ture'; Karata c':ũyi 'eagle', Andi c':un 'eagle, vulture' (B.13)

[I.76 = I.40] Basque *sain 'vein, root, nerve, root (of hair)' PEC * $\underline{s} \bar{e} \hbar m V / * \hbar \bar{e} m \underline{s} V$ 'muscle, vein; intestine' (A.58)

[I.77 = I.42] Basque *śoin 'shoulder, (upper) back', etc. PEC *Hçwēymă / *Hçwēynă 'leg bone' (A.38)

In the following cases a trace of the original nasal is left as Basque $/ \mathrm{n} /$ :

[I.78 = I.49] Basque *honda- $\dot{r}$ 'sand, residue, bottom' PEC *2amtV 'earth, ground' (D.18) ${ }^{38}$

[I.79 = I.50] Basque *hu[m]ki 'to touch'39 PEC *fimkwV 'fist' (V.13)

[I.80 = I.52] Basque *i=hunc 'dew' PEC *xw⿳亠幺⿲丿丨乚 $w \bar{t}$ 'bog, dirt' (E.11)

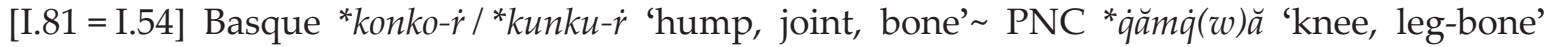
(A.76)

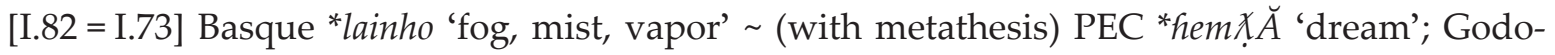
beri hanlu 'fog, cloud' (G.7)

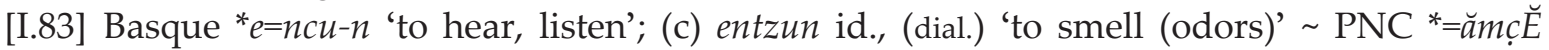
'to know, see'; Hunzib = $\tilde{a} c$ '- 'to see' (V.48)

[I.84 = I.67] Basque *Hainc-eihar 'frost' PNC *yămz $\breve{A}$ 'snow' (G.15)

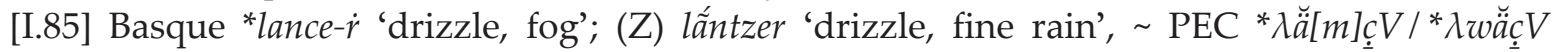
'to filter, sift'; Bezhta tatsa-ri 'sieve' (G.9) ${ }^{40}$

[I.86 = I.55] Basque *ondo1 'joint' PEC *2amdV 'joint, bone' (A.77)

[I.87] Basque *tanta, *tanto 'drop, dung pellet'; (c) tanta 'drop (of liquid)' PEC *tĕmtV 'dirt, dust'; Andi toto 'saliva' (E.13)

[I.88] Basque *tintV 'gland, uvula'; (BN) tinto-la 'uvula', PEC *têmț V 'freckle, spot'; Bezhta t'ot'i-lo 'pimple' (A.34)

\section{Archaic laryngeals in Basque}

The Basque aspirate $/ \mathrm{h} /$, which is still a contrastive phoneme in northern dialects $(\mathrm{L}, \mathrm{BN}, \mathrm{Z})$, and is attested in older texts of the southern dialects as well, is treated separately in FHV (52326) by Michelena, who "clearly assumed that a phoneme *h was found in Proto-Basque" (Jacobsen 1995: 123), while Trask (1995: 9) thought that the "pre-Basque aspiration was not etymological, but was merely a suprasegmental feature” (BCR 37).

38 Because this PEC reconstruction was based on only three Dagestanian languages, Tsezi, Hinukh, and Khinalug, the nature of the internal nasal (whether ${ }^{*} m$ or ${ }^{*} n$ ) was not clear. Based on the Basque evidence with the labial vowel /o/, * $m$ may be preferable for the PEuC stage.

39 In this word we have an unusual contrast between NE Basque /un/ /on/ (hunki-, onki-) vs. SW Basque /u/ $(u k i-)$, thus a tentative reconstruction ${ }^{*} h u[m] k i-$.

40 For semantic typology, cf. Swedish sil 'strainer', sila 'to strain; trickle, pour (of rain)', etc. 
In North Caucasian "laryngeals are the most unstable class of consonants ... Their exact reflexes are often hard to establish (especially in [Proto-Nakh] and [Proto-Andian], where in some cases we use the symbol H, denoting an arbitrary laryngeal)" (NCED 62). Even more so, in the reconstruction of Proto-Sino-Caucasian "laryngeals in general are very unstable phonemes and tend to disappear easily. They are most numerous and best reconstructed in PNC, with ... correspondences in other families" (SCP 22).

In Basque we can probably reconstruct, at the most, two laryngeals: ${ }^{*} h$, which remains as $/ \mathrm{h} /$ in all three of the aspirating dialects $\left(\mathrm{BN}, \mathrm{L}, \mathrm{Z}=\right.$ Basque dialects in France), and ${ }^{*} \mathrm{~h}$ which has the reflex $/ \mathrm{h} /$ in $\mathrm{BN}$ and $\mathrm{L}$ but zero in $\mathrm{Z}$. Whether this ${ }^{*} /{ }^{*} \mathrm{~h}$ opposition should really be traced back to Proto-Basque is, so far, uncertain; possibly it is the result of dialect borrowing or some other force. It is of interest, however, that the PNC uvular fricative ${ }^{*} \chi$ always corresponds to Basque ${ }^{*} h$, never to Basque ${ }^{*}$ (BCR 167-69).

Both ${ }^{*} h$ and ${ }^{*} h$ are lost in the non-aspirating dialects $(B, G, A N, R, B z t, A z k$, Sal = "Spanish" Basque dialects), except in some of the earliest records, and in some cases where old * $h$ between vowels has become the voiced velar continuant [r], phonemically /g/ and traditionally written as g, e.g. (B, G, AN) igar [i⿶ar] 'dry' < *eihar;; cf. PEC *hwēri 'morning, dawn' (BCR R.22), and (R, Bzt) agur [arur] 'palm, hollow of hand' < $a=h u \dot{r}$; cf. PEC * $k H w \bar{r} r V$ 'hole, pit' (BCR A.67).

Basque also preserves some laryngeals in combination with resonants, often with the laryngeals no longer existing as such in modern Caucasian languages. For example, the EC etymon represented by Avar q':warí-da-b 'narrow, cramped' was reconstructed by Nikolayev \& Starostin as PEC * $\dot{q} w a r H V$ 'thin, narrow' (NCED 933). The cognate proposed for this word is Basque *garhi, attested with /rh/ in northern Basque garhi 'thin, slender, slim, slim-waisted'; in some Lezgian languages, for example, the reflex of ${ }^{*} H$ may consist of a pharyngealized initial consonant, e.g. Agul q':ure- 'thin, emaciated'. ${ }^{41}$

Basque transposed laryngeals (in relation to PNC). In the following cases Basque has a laryngeal $* h$ between vowels or in clusters, while the hypothesized PNC or PEC cognate has a laryngeal in a different position or different vowel structure. Note the contemporary NC cognates with a laryngeal or pharyngeal (/h/, /h/, / / /, ///,/?/), or a pharyngealized vowel (/ạ/, /ẹ/, /ị/, /o/, /ụ//); ${ }^{42}$ laryngeals and pharyngeals can also influence accent patterns in Avar, ${ }^{43}$ and various other changes to vowels and consonants. ${ }^{44}$ Selected Basque and NC cognates are cited:

[II.1] Basque *barhe 'slug, snail'; (BN, L, Z) barhe 'slug' PEC *bHōr- (in *bHōr-XwVtV'snake, snail, worm'); Lak bạrčalu 'snail' (with pharyngeal /ạ/) (B.28) 45

41 "Pharyngealization (and the pharyngealization of uvulars in particular) [in Tsezian, Lak, Dargwa, Lezghian, Ubykh] is apparently the result of the fall of certain laryngeals ..., therefore we do not reconstruct a special pharyngealized uvular series for PNC" (NCED 59).

42 "Pharyngealized vowels in Lak, [Proto-Dargwa] and [Proto-Lezghian] usually correspond to each other rather well and can be traced to PEC fallen laryngeals (not only in initial combinations, but in medial clusters as well, ... In addition to Lak, Dargwa and Lezghian languages pharyngealization is also present in [Proto-Tsezian] and [Proto-West Caucasian]" (NCED 83).

43 "A typical feature of the emphatic laryngeals is that nouns that contain them reveal in Avar an immobile accent paradigm (the so-called 'Paradigm A'), while words with plain laryngeals (or without laryngeals) have in Avar either an oxyton or a mobile accent paradigm (paradigms B and C)" (NCED 62).

44 "One can also pay attention to the unmotivated variation of voice/voicelessness (and also glottalization) in some PWC reflexes. The reasons for a secondary voicing in PWC are not clear yet (it could be possibly connected with the fall of laryngeals in PWC)" (NCED 48); "The development of vowels is also influenced by pharyngealization (that appears as a result of the fall of laryngeals" (NCED 72).

45 Alternatively the PEC proto-form could have been *wHōr-, since all attested forms belong to languages in which $\mathrm{PNC}^{*} w$ and ${ }^{*} b$ have merged as $/ \mathrm{b} /$. The same situation holds for the next set. 
[II.2] Basque *berho 'bramble, thicket'; (L) berho id. PEC *bHŏrV 'a kind of thorny plant'; Lak burū 'thistle' (with pharyngeal /ụ/) $\left(\right.$ C.14) ${ }^{46}$

[II.3] Basque *bitho 'hair, mane'; (BN) bilho id. PNC * $\dot{p} V \hbar V t V$ 'feather, mane'; Dargi pạala 'feather' (with pharyngeal /ạ/ and voiceless pharyngeal fricative $/ \hbar /$ ) (A.20)

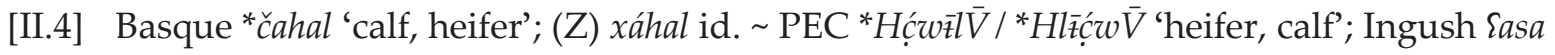
'calf', Avar Eač'ár 'heifer' (N.11)

[II.5 = I.24] Basque *čehume 'half-span'; (BN) xehume id. PNC *č $\breve{V} m \hbar V$ 'span'; Tsakhur č’̣̣m / čum, Agul čịb/ čẹb id. (with pharyngeal /ị/, /ụ/ or /ẹ/) (L.7)

[II.6] Basque *ethe 'word, speech'; (BN, L) elhe id. < +e=tehe PEC *lĕHwV/*tĕHwV 'word'; Dargi lusi 'number' (L.11)

[II.7] Basque * geHeti 'ox; beef, meat' / ${ }^{*}=/ o=k e t V ; 47$ (L-arc) geheli '(fresh) beef' (17th c.); (BN) ikhel 'fattened ox', (AN) ikela id.; (L) okhela, okheli 'meat; piece (of meat, cheese), morsel'

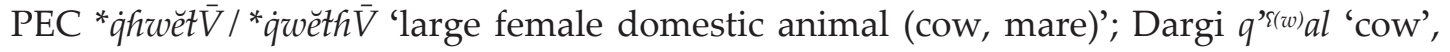
Lak ụl 'cow', Avar Salá 'mare'48 (P.12)

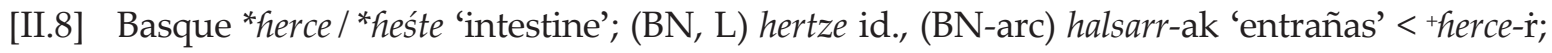
$\sim$ PNC * ${ }^{*} \breve{A} r H V /{ }^{*} H \breve{A r} r \check{V} V /{ }^{*} r H \breve{A} \breve{c} V /$ 'stomach, abomasum'; Avar forčo 'intestine', Andi ručo-1 id. (A.54; SCG 180)

[II.9] Basque *hodoe 'cloud'; (BN) hodei 'cloud, thunder' (with metathesis) PEC *dwiHV 'wind'; Dargi dạ id. (with pharyngeal /ạ/ and voiced pharyngeal fricative / / /) (G.4) ${ }^{49}$

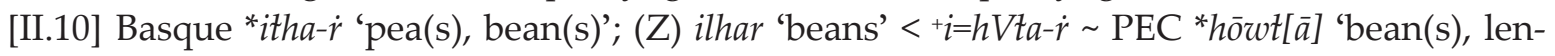
til'; Tsezi hil 'pea(s)', Avar holó 'bean(s)' (O.8)

[II.11] Basque *lahar 'thorn, bramble'; (BN, L) lahar 'bramble, creeping thorn', (Bzt) lagar id. PEC * X.w $w \breve{r} z V$ 'leaf'; Karata (Tokita dial.) alzi , Lezgi riq's-äy id. (C.17) ${ }^{50}$

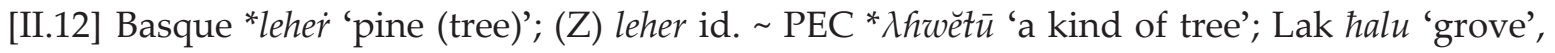
Lak (Arakul dial.) xwạlu id., Avar t:alú 'yew-tree' (C.7)

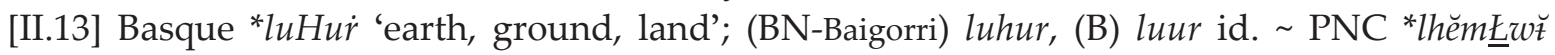
'earth'; Avar ratt': 'earth, ground', Tsakhur (Gelmets dial.) nọk 'field' (with pharyngeal /ọ/) $(\mathrm{D} .1)^{51}$

[II.14 = I.2] Basque *mahać 'grape(s)' PNC *\{ämćō 'apple; medlar' (P.17)

[II.15 = I.8] Basque *maruhi / *mahuri 'strawberry' PEC *mer(2)V 'a kind of berry'; Lezgi mere 'blackberry' (P.18) 52

[II.16] Basque *sahar 'old' (human), 'old person'; (BN, L) zahar 'old (human, animal, plant), old person', (Bzt) zagar id. PNC *swĕrho / *r(h) ĕswo 'old; year'; Avar asrá-ya- 'old, worn out' (R.40)

46 *bHŏrV or *wHŏrV (see the preceding note).

47 Here we have an unusual case of the extended, unprefixed form *geHeti coexisting with forms with fossilized class prefixes (articles), ik(h)el(a), ok(h)eli/a; in the latter the syllabic structure is syncopated from three to two syllables and the initial plosive is devoiced, which also occurs in a few other etymologies (BCR 128-29).

48 Note Dargi pharyngealized /q'§(w)/, Lak pharyngeal /ụ/, Avar pharyngeal fricative / //.

49 For semantic connections of 'wind' 'cloud', cf. Basque *haise 'wind' Akhwakh as:i 'breath' Udi haso 'cloud', etc. (BCR G.3).

50 The Lezgi form represents metathesis (< Proto-Lezgian *ri X! ${ }^{w}-$ ). For semantic typology of 'leaf' 'thorn' cf. Old Indic trína- 'grass, blade of grass, straw', Slavic trŭnŭ 'thorn', Gothic paurnus, Eng. thorn, etc. (Buck 8.51).

51 Initial Avar /r/ and Tsakhur /n/ are the regular reflexes of PNC initial *l-, when preceding *- $m$ - in the same root; Avar /t'”:/ and Tsakhur /k/ are the regular reflexes of the PNC tense lateral affricate ${ }^{*} \succeq$ (NCED 53, 55, 131).

52 Here NCED suggests a laryngeal with the notation (2). The Basque evidence for $/ \mathrm{h} /$ is quite clear. 
[II.17] Basque *solho 'meadow, field'; (L) sorho 'meadow' 53 PEC *čHätu 'earth, ground, sand'; Lak š:alu 'earth, ground' (with pharyngeal /ạ/) (D.3)

[II.18 = I.33] Basque *sumhe 'a kind of tree'; (Z) zünhar 'a kind of elm tree', (Sal) zugar id.

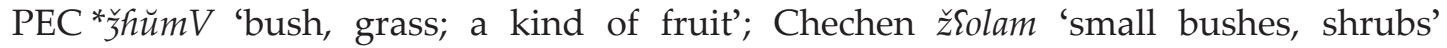

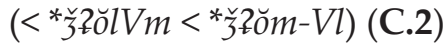

PEuC medial laryngeal clusters: In each of these cases northern Basque retains $/ \mathrm{h} /$ in a resonant $+/ \mathrm{h} /$ cluster $/ \mathrm{Rh} /$, and the PNC/PEC cognate also has a /Rh/ cluster, usually in the same order as in Basque; there are two possible cases of metathesis [II.27, II.28]. Selected Basque and NC cognates are cited:

[II. 19] Basque *arhe 'harrow, rake'; (BN, L) arhe id. <+harhe PEC * ${ }^{*} a r h V$ 'harrow'; Avar sár-ize 'to harrow', sári 'wooden ladder' (Q.14)

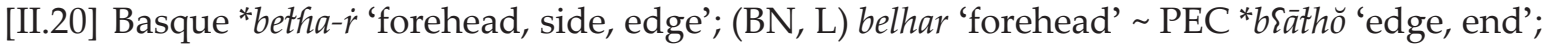
Lezgi p:el, Kryz bel 'forehead' (A.5)

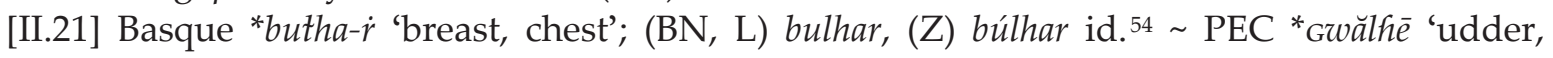
breast'; Avar swári 'udder' (A.40)

[II.22] Basque *bur(a)ho 'curse, blasphemy, hatred'; (BN, L) burho, (B, G) birago PEC *Gwätho 'gossip, rumor; offence, anger'; Avar $\boldsymbol{H}^{w}$ el 'gossip, rumor; abuse', Tsakhur qal 'offence, anger' (K.1)

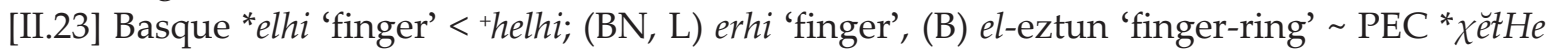
'sleeve'; Rutul xili-di 'mitten' (A.69)

[II.24] Basque *ethi 'cattle, herd'; (L) elhi 'cattle, livestock, herd, flock' < thethi PEC * $\chi$ wōlhV / * $\chi H w \bar{o} l V$ 'cattle, cows'; Chechen $\hbar \bar{e} l i$ ' cows' (N.5)

[II.25] Basque *garhi 'thin, slender'; (BN, L) garhi 'thin, slender, slim, slim-waisted' PEC *'qwarHV 'narrow, thin'; Agul q`:ure- 'thin, emaciated' (R.59)

[II.26] Basque * gurhi 'butter, grease'; (Z) gurhi 'fat, grease, butter' PEC * $\chi \partial r H V /{ }^{*} \chi H a r V$ 'but-

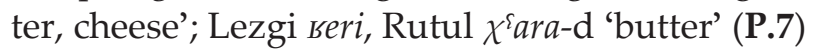

[II.27] Basque *ithu-n 'dark, night'; (BN) ilhun 'night' < PEuC + XilHu- (with metathesis) PNC *2lē $\chi \breve{a}$ 'night'; Chamali yeta, Tindi reta id. (R.18)

[II.28 = I.73, I.82] Basque *lainho 'fog, mist, vapor' (with metathesis) PEC *hem Xִ. 'dream'; Godoberi hanlu 'fog, cloud' (G.7)

[II.29 = I.5] Basque *manhai 'table' PEC *mfăznē ‘door; part of door' (Q.9)

Archaic Basque laryngeals, apparently lost in PNC: There are four cases, all involving PNC/PEC tense sibilants ( $\left.{ }^{*} \underline{\underline{S}},{ }^{*} \underline{{ }^{\prime}},{ }^{*} \underline{\underline{z}}\right)$, in which the Basque cognate contains an internal laryngeal, but the PNC/PEC cognate does not. In NCED there is a hint that may explain this: "The [PEC] root ['śswăyV] 'last year' may have also contained a laryngeal," based on the pharyngeal vowel /ạ/ in Archi š šă 'last year' (NCED 975). The implication may be that Basque preserves an archaic laryngeal that was lost in PNC/PEC or absorbed into the tense sibilant, in the case of the 'last year' set and the other three sets.

[II.30] Basque *ihas 'last year'; (Z) ihaz, (B, G, AN) igaz [iðas] id. < PEuC +iHaśV (with metathesis) PEC *śswăyV 'last year' (<+śwăyHV or +śHwăyV ?); Chamali sas:, Archi šwạs id. (H.3)

[II.31]Basque *sathui 'quick, nimble, flexible', etc.; (L) zalhui id. PNC *sittV 'light (of weight)' $\left(<{ }^{+}\right.$sitHV or ${ }^{+}$sHitV?); Archi s:ala id. (R.42)

53 The supposed derivation of this word from Latin solum (or a Romance descendant) is rejected here, for phonetic and semantic reasons; the corresponding loanword in Basque is (G) zoru 'ground, floor', (B, G) 'sole (of shoe)' (see BCR 238).

54 One of the cases of $\mathrm{PEuC}{ }^{*} \mathrm{G} w>$ Basque * $b$ : see also the next set, and BCR 93-94, 167. 
[II.32] Basque *sethai 'plain, prairie'; (BN, L) zelhai 'plain, flat land', 'flat' (adj.) PEC *z̧alV 'plain, plateau' (<+zalHV or +3HalV?); Avar c':or 'plain' (D.5)

[II.33]Basque *sutho 'hole'; (BN, L) zulho, zilho 'hole, burrow', (B) sama-zulo 'gullet' ('necktube') PEC *śswōtV 'hollow tube' (< +śwōtHV or +śHwōtV?); Avar šulu 'pipe', Lezgi sulu-r 'throat' (I.12)

\section{Basque $/ \mathrm{rc} / \sim /$ śt/ stem alternation}

As noted by Michelena (FHV 363-65), in a very few cases Basque exhibits a stem alternation between medial/final /rc/ and /śt/. It so happens that PNC provides a key, since these Basque words correspond to NC words containing PNC clusters of ${ }^{*} r+$ sibilant affricates $\left({ }^{*} c,{ }^{*} c^{*}{ }^{*} \check{c}\right)$ :

[III.1] Basque *borc / *bośt 'five', *bośte-ko 'hand' PEC *b[a][r]cV 'paw; part of arm or leg'; Tsezi besi 'fist', Tabasaran bac 'paw' (M.6) ${ }^{55}$

[III.2 = II.8] Basque *herce / *heśte 'intestine'; (BN, L) hertze, (B, G, AN) este id. PNC *HĂrčV/ * $r H \breve{A c} V / * \check{c} \breve{A r H V}$ 'stomach, abomasum'; Avar Sorčo 'intestine', Andi ručo-l, Chechen čü-r-aš 'intestines' (A.54; SCG 180)

[III.3] Basque *horci / Fośti 'sky, storm'; (L) hortz-adar, holtz-adar 'rainbow',56 (B) osti 'storm, thunder' PEC *HārčwVn 'to become cloudy, gloomy'; Karata (Anchikh, Archo dial.) orč'to become cloudy', Avar róč:n- id. (G.12)

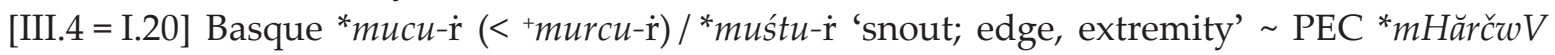
'pus; mucus, snot' (A.19)

[III.5] Basque *Perc / Peśt 'cauldron, pail'; 57 (G, AN) pertz, (AN, BN, Bzt, Z, R) bertz, (BN-ms) best PEC * parćé 'water jug'; Avar parči i 'earthenware water jug'. (Q.23)

The distribution of /rc/-forms /śt/-forms is not regionally determined in Basque: for example, bost 'five' prevails both in the far west $(\mathrm{B}, \mathrm{G})$ and far east $(\mathrm{Z}, \mathrm{R})$, with bortz, borz in most of the more central dialects; este 'intestine' is mostly southwestern (B, G, AN), with (h)er(t)ze elsewhere; the same dialect may have both variants of *horci / *hośti: (BN-Garazi) ortzi 'storm cloud' / ostegun 'Thursday'; (Z) ortze 'storm' / ostégün 'Thursday', etc. (See the long lists of related words in EDB 316-19; Trask 1997: 278.)

Michelena sought to explain this alternation as stemming from a sandhi feature in compounds, in which a multistep change of ${ }^{*} r t z>{ }^{*} r z t>{ }^{*} r s t>{ }^{*} s t /$ st/ occurred. Whatever the mechanism, it is likely that *berc, *borc, *herce, *horci, *mu(r)cu-rir were originally the freestanding nouns, and *best-, *bośt-, "heśt-, *hośt-, ${ }^{*} m u s ́ t u-$, respectively, were the stem variants used in compounds or before suffixes. Subsequently the two allomorphs were confounded and merged, so that the /rc/-forms could then be used in compounds, and /śt/-forms in freestanding forms. It is interesting that the Basque words with this alternation all have NC cognates with the rhotic + sibilant clusters ${ }^{*} r c,{ }^{*} r{ }^{\prime},{ }^{*} r \check{c} .58$

55 Problematic: outside of Basque the cluster * $r c$ is supported only by Avar púrc: $i$ 'ham' (which may be secondary, <*bVc:-ri: see NCED).

56 The L words are compounds with *a=dar 'horn', i.e. 'sky-horn'; the form holtz (for hortz) by dissimilation from the following rhotic.

$57 * P$ signifies "some labial stop," since attested forms have both /p/ and /b/.

58 Except Basque *berce / *beśte 'other', for which a satisfactory NC cognate has not been found. Possibly it is related in some way to Basque *bi 'two' (cf. Udi $p: a$, Lak (Kumukh dial.) $p k$ ' $i$ 'two' < PNC * $\dot{q} H w \bar{a}$ id.), as in the common semantic link of 'second' and 'other'. 
In the following cases Basque has ${ }^{*}$ śt or ${ }^{*}$ st corresponding to a PNC ${ }^{*} r+$ sibilant cluster, but without any known stem alternations:

[III.6] PEuC *r[...]ś: Basque *aśtu-n 'heavy'; (B, G) astun 'heavy, weighty; important, serious'

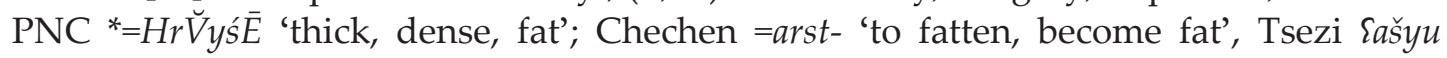
'thick (of a flat object)' (R.29)

[III.7] PEuC *rš: Basque *b=uśte-1 'rotten'; (L) bustel, (Z) üstel id. PNC *=Vrš $\bar{E}$ 'to rot, ferment'; Dargi (Chiragh dial.) =arš- / =urš- 'to rot', Udi bašs $a(y)$ 'rotten' (b=aš $a-$ ?) (R.45) ${ }^{59}$

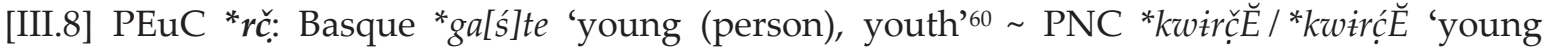
(of animals, birds)'; Lak karč 'puppy', Khwarshi k'uč'i id. (R.66)

\section{Conclusions}

It is affirmed here, based on ample evidence, that a phoneme ${ }^{*} m$ did exist in Proto-Basque, as well as in Proto-Euskaro-Caucasian, and that it remained quite stable in Basque in most initial and medial environments. But $\mathrm{PEuC}^{*} m$ did indeed disappear, or change to $/ \mathrm{n} /$, especially in reflexes of internal PEuC clusters. Thus Trask's doctrine that "no * $m$ can be reconstructed for Pre-Basque" (based on a more cautious suggestion by Michelena) turns out to contain a small smidgen of truth.

There is also copious evidence that the Proto-Basque laryngeals ${ }^{*} h$ and ${ }^{*} h$ are preserved intact in northern Basque reflexes of the same words in which a laryngeal is postulated for Proto-North Caucasian or Proto-East Caucasian (according to NCED). In internal clusters northern Basque frequently preserves these laryngeals in cases where there is only circumstantial evidence of them in modern North Caucasian languages (e.g., as pharyngealized consonants and vowels, or as particular accentual patterns). This is one of several ways in which Basque is more conservative than its cousins, the North Caucasian languages.

At the same time, Basque naturally exhibits some important innovations. Phonetically, a much simpler vowel and consonant system developed in Basque than Proto-EuskaroCaucasian is thought to have had (BCR chapter IV). Grammatically, the Euskaro-Caucasian noun class system loses its productivity, but leaves traces in fossilized prefixes such as * $b e^{*} b i=$, ${ }^{*} e^{*} i={ }^{*} O{ }^{*} u=$, etc. (BCR chapter V). Lexically there is, for example, the development of a new word for 'eye', * $b=e g i$ (originally 'seer', cf. PEC * $=a g w V$ 'to see'), while North Caucasian ( ${ }^{*} z w \breve{l l} i$ 'eye'; Dargi ule, Abkhaz á-la), Burushaski (*-l-ći / *il- 'eye') and Yeniseian (*de-s 'eye') ${ }^{61}$ retain the older form, which Basque preserves only in the truncated form *le- in words for 'eye-tooth' ( ${ }^{*} l e$-t-agin), and in the verb *uter-tu 'to understand, comprehend; foresee, suspect; feel, sense' (see BCR, etymologies A.8, A.11, A.12, V.14). ${ }^{62}$ Other Basque innovations are evident, for example, in kinship terminology and numeral words that are radically different from those of North Caucasian; here we see the results of innovations on both sides (see BCR 329-336; 344-48).

Greenberg (1995: 207) refers to an essential attribute of a "best explanation" hypothesis of linguistic relatedness. "Such hypotheses have a further important characteristic, which we may call fruitfulness, That is, they can be built upon and lead to further discoveries and explanations of hitherto puzzling phenomena." Seven decades earlier Edward Sapir had written in

59 Udi possibly has the same fossilized class prefix $\left({ }^{*} b=\right)$ as postulated in the Basque form.

60 The reconstruction * $g a[s ́] t e$ is provisional, since dialectal evidence /gaste/ /gaśte/ is ambiguous.

61 Proto-Yeniseian lacks initial laterals, and the initial resonants ${ }^{*} l$-, ${ }^{*}$ - and ${ }^{*} n$ - regularly become ${ }^{*} d$ - (SCP 38, 68).

62 George Starostin proposed the ${ }^{*} b=e g i$ and ${ }^{*}$ uter-tu etymologies. The Basque verb is typologically similar to

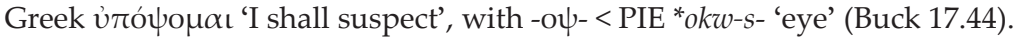


a letter that the Sino-Dene hypothesis "is all so powerfully cumulative and integrated that when you tumble to one point a lot of others fall into line" (letter to Alfred Kroeber in 1921, quoted in Golla 1984: 374). So it is with the Euskaro-Caucasian hypothesis. Just within the small selection of etymologies discussed here, several of them figure in more than one of the three major topics discussed: [I] the labial nasal * $m$; [II] archaic Basque laryngeals; [III] the /rc/ /śt/ alternation, for example:

[I.2] = [II.14] Basque *mahać 'grape(s)' PNC * ¿ämćó 'apple; medlar';

[I.8] = [II.15] Basque *maruhi / *mahuri 'strawberry' PEC *mer(2)V'a kind of berry';

[I.5] = [II.29] Basque *manhai 'table' PEC *mfăznē 'door; part of door';

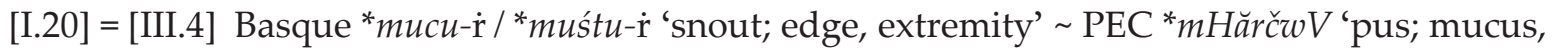
snot';

[I.24] = [II.5] Basque *čehume 'half-span' PNC *çّ̆ $m \hbar V$ 'span';

[I.33] $=$ [II.18] Basque *sumhe 'a kind of tree' PEC *̌̌̆ŭmV'bush, grass; a kind of fruit';

$[\mathrm{I} .73]=[\mathrm{I} .82]=[\mathrm{II} .28]$ Basque *lainho 'fog, mist, vapor' $\sim$ PEC *hem 'fog, cloud';

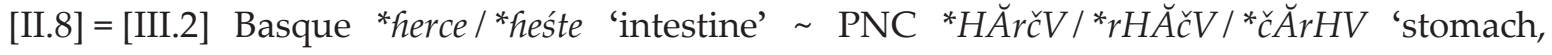
abomasum'; Avar Sorčo 'intestine'.

These and other cases function as a kind of cross-validation (the same etymology confirmed by more than one rule), and exemplify what Sapir meant by "when you tumble to one point a lot of others fall into line."

\section{General notes to etymologies}

1. The fossilized plural or collective suffix * ${ }^{*} \dot{r}$ occurs in many Basque nouns (see BCR 76-78). In this paper see

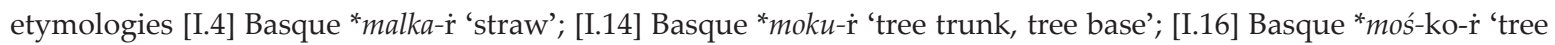

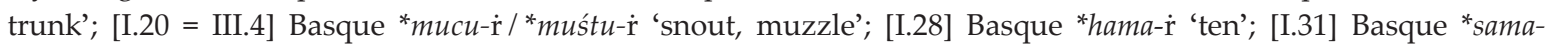

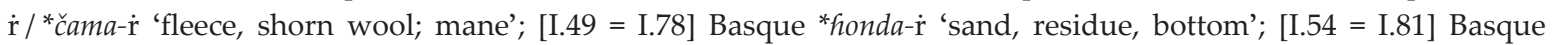

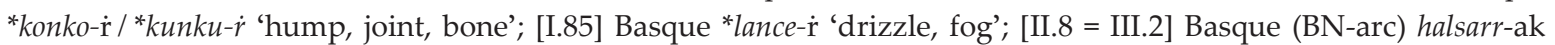

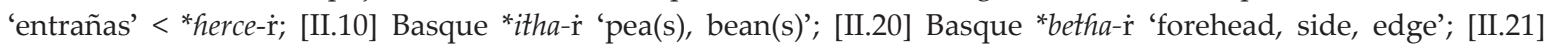
Basque *butha-rir 'breast, chest'.

2. Basque correspondences to PNC lateral affricates $* x, x^{*}\left(=x^{\prime}\right),{ }^{*} \boldsymbol{t}$ in initial (Anlaut) position. Basque laterals are very simple: only the resonant /1/ appears in initial position: see [I.27] Basque *(eci-)[lamu] 'two days after tomorrow' $\sim$ PEC ${ }^{*} \measuredangle \breve{V} m V$ 'one day (two days) after tomorrow'; [I.30] Basque *limu-ri 'slippery, moist, smooth', etc. PEC * XِHwemV 'liquid' (adj.); [I.47] Basque *listo- 'hornet, wasp' PEC *XămçV 'a biting insect'; [I.73] Basque *lainho

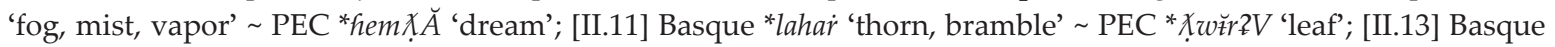

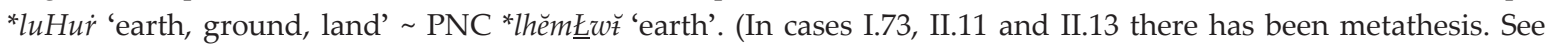
BCR 154-55 for further examples and explanations.)

3. Basque correspondences to PNC lateral affricates * $x, * x\left(=x^{\prime}\right),{ }^{*} \boldsymbol{t}$ in medial (Inlaut) position. There are two main reflex types, (a) Basque /rd/, and (b) Basque /rt/. See BCR 156-58 for further examples and a possible explanation of reflex (a) vs. (b). In this paper, with reflex type (a), see etymologies [I.7] Basque *mardo 'robust; luxuriant',

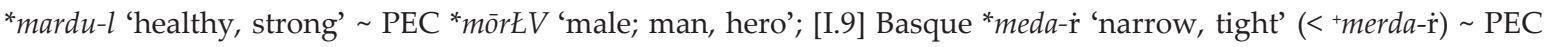
* $h m \bar{V} \not \underline{\underline{V}} \breve{V}$ 'thin, narrow'; [I.15] Basque *mardo 'bunch, group' PEC *mär [X]o 'handful, armful'; With reflex type (b) see [I.21] Basque *muti-1 'boy; apprentice; worker' (<+murti-1) PNC *mŭlx̆V 'husband, male, worker'. The Basque reflexes are the same whether the proto-phoneme was simple (e.g., *-X.-) or in a cluster with a resonant (e.g., *-rE-, *-rX-, *-lX̣-).

4. Matches between Basque and NC vowels may reflect a hypothetical Euskaro-Caucasian apophony (Ablaut) system (see BCR 106-110). The clearest evidence for such a system are found in some lexicalized traces in Basque, for example the Basque adjective *ośo 'whole, complete' (R.65) and the verb *aśe 'to be filled, satiated' (V.66), par-

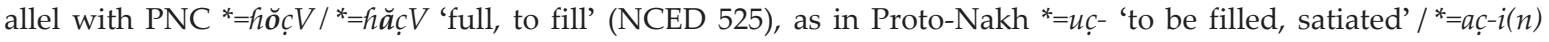


'heavy' (Chechen = üz-na 'full' / =eza 'heavy'), corresponding to Bsq *ośo / *aśe, respectively. As regards PNC nouns, this system was based on an opposition of mid vowels for the direct case vs. high vowels for oblique cases (see

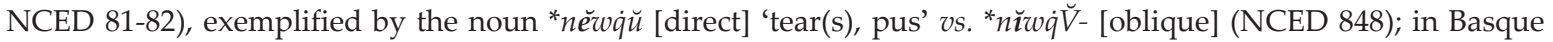
this alternation was lexicalized as regional variants, southwestern Basque negar 'weeping; tear(s)' vs. northeastern Basque nigar id. (BCR 106-07; A.78). A hypothesis needing further testing suggests that some vowel matches, such as ${ }^{*} i \sim{ }^{*} e$, in [I.30] Basque *limu-ri 'slippery, moist, smooth' PEC * XHwemV 'liquid', and [I.48] Basque *sisa-li 'worm', 'sisa-ni 'leech' PEC *sēmsā 'tadpole, water flea, bug, ant', could have resulted from the lexicalization of different apophonic allomorphs.

5. It is postulated in BCR that certain initial syllables in Basque derive from fossilized remnants ("stage III articles") corresponding to the class/gender markers in Proto-North Caucasian that persist in most of the modern NC languages (BCR 11-12; 58-71). It happens that within the collection of etymologies in the current paper there are a few examples of the fossilized articles ${ }^{*} \boldsymbol{e}=,{ }^{*} \boldsymbol{i}=$ and ${ }^{*} \boldsymbol{o}=$ : see [I.47] Basque ${ }^{*} \boldsymbol{e}=l_{c o}$ 'gnat, midge, mosquito' $\sim$ PEC

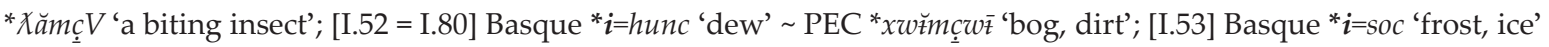
$\sim$ PEC *zwVnć(w)V 'snowdrift, snowstorm'; [I.63] Basque *e=roic 'cliff, fissure' PEC *hrŏmçwe 'stone'; [II.6] Basque ${ }^{*} \boldsymbol{e}=$ the 'word, speech' < +e=tehe $\sim$ PEC *lĕHwV / ${ }^{*} t \breve{e} H w V$ 'word'; [II.7] Basque *i=ketV 'fattened ox' / *o=ketV 'meat;

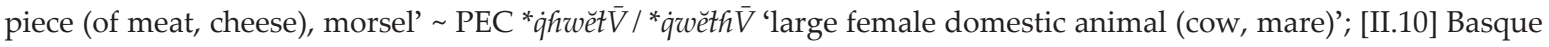

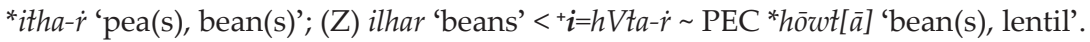

6. Reconstructions: Reconstructions based on attested forms are designated by [*], in the usual manner. More speculative or less substantiated “quasi-reconstructions” are designated by $\left[^{+}\right]$. For example, PEuC ${ }^{+} H a \underline{G} \underline{i} m V$ 'tooth' is a possible, but not necessarily the only solution to reconciling Basque *hagin 'tooth' and PNC *HĕmĞ $\breve{A}$ 'to bite', by a common type of transposition (see I.38); likewise PEuC ${ }^{+} e=t e h e$ is a possible, but not necessarily the only conceivable intermediate form between Basque *ethe 'word, speech' and PEC *lĕHwV/ *tĕHwV 'word' (see II.6).

\section{Abbreviations of languages and dialects}

$\begin{array}{ll}\text { A } & \text { Araban: old Basque dialect of Araba (Álava) province (= Michelena's meridional) } \\ \text { AN } & \text { Alto Navarro = High Navarrese (Basque dialect) } \\ \text { arc } & \text { Archaic or obsolete form } \\ \text { Azk } & \text { Aezkoan (Basque dialect) } \\ \text { B } & \text { Bizkaian = Biscayan (Basque dialect) } \\ \text { Bzt } & \text { Baztanese (Basque dialect) } \\ \text { BN } & \text { Bas-navarrais = Low Navarrese (Basque dialect) } \\ \text { c } & \text { Common Basque: the form in all dialects / or the most widespread form } \\ \text { dial. } & \text { dialectal } \\ \text { EB } & \text { euskara batua (standard Basque) } \\ \text { G } & \text { Gipuzkoan (Basque dialect) } \\ \text { L } & \text { Lapurdian = Labourdin (Basque dialect) } \\ \text { PEC } & \text { Proto-East Caucasian } \\ \text { PEuC } & \text { Proto-Euskaro-Caucasian } \\ \text { PNC } & \text { Proto-North Caucasian } \\ \text { PWC } & \text { Proto-West Caucasian } \\ \text { R } & \text { Roncalese (Basque dialect) } \\ \text { Sal } & \text { Salazarese (Basque dialect) } \\ \text { Z } & \text { Zuberoan = Souletin (Basque dialect) }\end{array}$

\section{Abbreviations of sources}

\footnotetext{
BCR Bengtson (2017)

Buck Buck (1949)

CDIAL Turner (1962-66)

EDB Trask (2008)
}

FHV Michelena (1990)

NCED Nikolaev, Starostin (1994)

OEH Michelena (1987-)

SCG Starostin (2005b) 


\section{References}

Aulestia, Gorka, Linda White. 1992. Basque-English English-Basque dictionary. Reno, Nevada: University of Nevada Press. Azkue, Resurección María de. 1905-1906. Diccionario vasco-español-francés/ Dictionnaire basque-espagnol-français. Bilbao / Paris: The Author / Paul Geuthner.

Bancel P.J., A. Matthey de l'Etang, J.D. Bengtson. 2015. Back to Proto-sapiens (Part 2): The global kinship terms PAPA, MAMA, and KAKA. In D. Jones \& B. Milicic (eds.). Kinship, language, and prehistory: Per Hage and the renaissance in kinship studies: 38-45. Salt Lake City: University of Utah Press.

Bancel P.J., A. Matthey de l'Etang. 2013. Brave new words. In: C. Lefebvre, B. Comrie, H. Cohen (eds.). New perspectives on the origins of language: 333-377. Amsterdam: John Benjamins.

Bengtson, John D. 2017. Basque and its closest relatives: a new paradigm. Cambridge, Mass.: Mother Tongue Press / Association for the Study of Language in Prehistory.

Bengtson, John D. \& George Starostin. 2015. The Dene-Sino-Caucasian hypothesis: state of the art and perspectives. Discussion draft posted on Academia.edu, 2015.

Buck, Carl Darling. 1949. A dictionary of selected synonyms in the principal Indo-European languages. Chicago: University of Chicago Press.

Dryer, M. S., M. Haspelmath (eds.) 2013. The world atlas of language structures online. Leipzig: Max Planck Institute for Evolutionary Anthropology. Available at: http://wals.info/ [accessed 08.15.2018].

Golla, Victor, ed. 1984. The Sapir-Kroeber correspondence: letters between Edward Sapir and A.L. Kroeber 1905-1925. Berkeley: University of California Press.

Greenberg, Joseph H. 1995. The concept of proof in genetic linguistics. Mother Tongue 1: 207-216.

Jacobsen, William H. Jr. 1995. Comment on R.L. Trask's 'Basque and Dene-Caucasian: a critique from the Basque side'. Mother Tongue 1: 120-142.

Meyer-Lübke, Wilhelm. 1911. Romanisches etymologisches Wörterbuch. Heidelberg: Carl Winter.

Michelena, Luis. 1957. Las antiguas consonantes vascas. In: D. Catalán (ed.). Miscelánea homenaje a André Martinet, vol. I: 113-157. Tenerife: Universidad de La Laguna.

Michelena, Luis. 1961. Fonética histórica vasca. San Sebastián: Diputación Provincial de Guipúzcoa.

Michelena, Luis [Koldo Mitxelena]. 1987-. Orotariko euskal hiztegia / Diccionario general vasco. Bilbao: Euskaltzaindia. [Edited since Michelena's death by Ibon Sarasola.] Available: http://www.euskaltzaindia.eus/index.php? option=com_content\&view=article\&id=276\&Itemid=413\&lang=eu/ [Accessed 08.15.2018].

Michelena, Luis [Koldo Mitxelena]. 1990. Fonética histórica vasca. (Anejos del Anuario del Seminario de Filología Vasca «Julio de Urquijo», IV Serie «Obras completas de Luis Michelena», 1.) San Sebastián: Diputación Foral de Guipúzcoa. [Reprint of $2^{\text {nd }}$ edition.]

Nikolaev, Sergei L., Sergei A. Starostin. 1994. A North Caucasian etymological dictionary. Moscow: Asterisk Press.

Ruhlen, Merritt. 1975. A guide to the languages of the world. Stanford: Language Universals Project.

Starostin, Sergei A. 1996. Response to Trask [1996]. Mother Tongue 2: 119-123.

Starostin, Sergei A. (ed.). 1998-2005. The Tower of Babel. An etymological database project. Available at: http://starling.rinet.ru/ [accessed 08.15.2018].

Starostin, Sergei A. 2005a. Sino-Caucasian [phonology]. http://starling.rinet.ru/Texts/scc.pdf

Starostin, Sergei A. 2005b. Sino-Caucasian [comparative glossary]. http://starling.rinet.ru/Texts/glossary.pdf

Steinbergs, Aleksandra. 1996. Intimate body parts and related terms in proto-Baltic. In: H. I. Aronson (ed). Linguistic studies in the non-Slavic languages of the commonwealth of independent states and the Baltic republics: 337-357. Chicago: Chicago Linguistic Society.

Trask, R. L. 1995. Basque and Dene-Caucasian: a critique from the Basque side. Mother Tongue 1: 3-82.

Trask, R. L. 1996. Second response to Starostin [1996]. Mother Tongue 2: 125-129.

Trask, R. L. 1997. The history of Basque. London/New York: Routledge.

Trask, R. L. 2008. Etymological dictionary of Basque. Ed. by Max W. Wheeler. University of Sussex. Linguist List Publications: http://www.sussex.ac.uk/linguistics/1-4-1-2.html

Turner, R. L. 1962-66. A comparative dictionary of Indo-Aryan languages. London: Oxford University Press. 
Джон Бенгтсон. Заметки об эускара-кавказской фонологии

Статья посвящена обоснованию ряда особенностей фонологической системы, реконструируемой для праэускара-кавказского языка (предполагаемого общего предка баскского и северокавказских языков) и опубликованной в недавней монографии автора. Детальному анализу подвергаются следующие моменты: (I) развитие праэускаракавказского сонанта * $m$ в баскском; (II) отражения эускара-кавказских ларингалов в неначальной позиции в баскском; (III) чередование /rc/ /śt/ в алломорфах некоторых баскских именных основ. В статье показано, как сценарий, предлагаемый для праэускарокавказского, позволяет объяснить ряд важных нерешенных проблем в исторической фонологии и морфонологии как баскского языка, так и северокавказской семьи.

Ключевые слова: баскский язык, северокавказские языки, сравнительное языкознание, эускара-кавказская языковая семья, губные носовые, ларингалы 